\title{
What has been happening to Internal Labour Migration in South Africa, 1993-1999?
}

\author{
Dorrit Posel \\ Division of Economics, University of Natal, Durban \\ posel@nu.ac.za \\ Daniela Casale \\ Division of Economics, University of Natal, Durban \\ casaled@nu.ac.za
}




\section{Abstract}

This paper attempts to redress the lack of research into temporary labour migration at a national level in South Africa. Using the 1993 Project for Statistics on Living Standards and Development and the 1995, 1997 and 1999 October Household Surveys, we explore three broad areas: the extent of labour migration over the period 1993 to 1999; the characteristics of migrant workers and how these have changed over time; and the economic ties that labour migrants have maintained with their households of origin. We find that labour migration from African rural areas has increased, driven largely by a rise in the proportion of women leaving their households of origin to work or to search for work. Using a simple multivariate regression analysis together with descriptive statistics, we explore some possible reasons for why there has been this increase in female migration. We also find that over the period migrants have retained strong economic ties with their households of origin, and that remittances remain an important share of income for these households. However, the analysis is limited by the paucity of data that exist on labour migrants in the national household surveys. We therefore have also sought, wherever possible, to expose the limitations of the data and the likely biases that result.

\section{Acknowledgements}

The authors would like to thank Prof Oded Stark and the participants at the 2nd Annual Conference on Labour Markets and Poverty of the Development Policy Research Unit for their comments. Daniela Casale would also like to thank the IRD, France for their funding of her research.

Development Policy Research Unit

Tel: +2721650 5705

Fax: +27216505711
Information about our Working Papers and other published titles are available on our website at: http://www.commerce.uct.ac.za/dpru/ 


\section{Table of Contents}

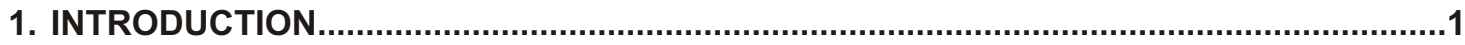

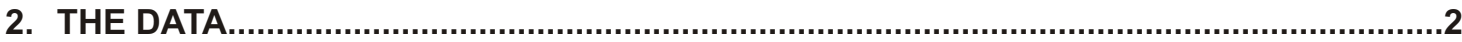

3. PATTERNS AND TRENDS IN LABOUR MIGRATION, 1993-1999....................................

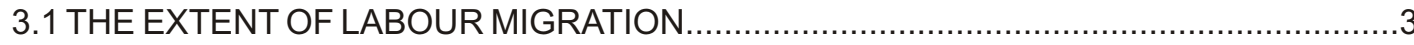

3.2 DETERMINANTS OF AND CHANGES IN FEMALE LABOUR MIGRATION......................6

3.3 THE ECONOMIC TIES OF LABOUR MIGRANTS ..........................................................

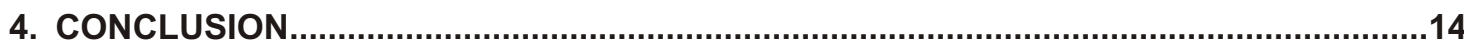

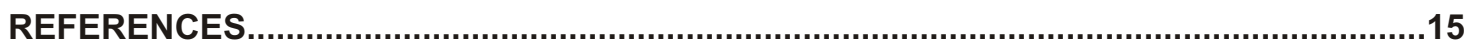

\section{List of Tables}

TABLE 1: MIGRANT WORKERS BY RACE GROUP (15 YEARS AND OLDER). .3

TABLE 2: THE EXTENT OF TEMPORARY LABOUR MIGRATION ACROSS HOUSEHOLDS..4 TABLE 3: AFRICANADULTS (15 YEARS AND OLDER) WHO ARE MIGRANT WORKERS.....5 TABLE 4: AFRICAN MIGRANT WORKERS BY GENDER (15 YEARS AND OLDER).

TABLE 5: PROPORTION OF AFRICAN MIGRANT WORKERS BY AGE COHORT AND GENDER (URBAN AND RURAL COMBINED).........................................

TABLE 6: THE DESTINATION OF AFRICAN LABOUR MIGRANTS ....................................

TABLE 7: ESTIMATING AFRICAN FEMALE LABOUR MIGRATION FROM RURAL AREAS, 1993.

TABLE 8: MARITAL RATES AMONG AFRICAN WOMEN(15 YEARS AND OLDER)....... .9

TABLE 9: PERCENTAGE OF RURAL AFRICAN HOUSEHOLDS WITH NO EMPLOYED MEN (AGED 15-64 YEARS)..

TABLE 10: AVERAGE NUMBER OF EMPLOYED RESIDENT MEN (AGED 15-64 YEARS) IN AFRICAN RURAL HOUSEHOLDS...

TABLE11: AFRICAN RURAL HOUSEHOLDS WITH MALE AND FEMALE MIGRANT WORKERS.

TABLE 12: REMITTANCES RECEIVED IN RURAL AFRICAN HOUSEHOLDS. 


\section{Introduction}

Labour migration in South Africa historically occurred under specific institutional conditions, where a range of measures made permanent urban settlement impossible for most migrants. With the lifting of formal sanctions against African urbanisation, it might be expected that patterns of circular or temporary labour migration would be replaced by permanent migration, and particularly to urban areas, and that migrants' ties to their households of origin would have considerably weakened. The period after the ending of Influx Control, however, has been associated with further changes that are likely to impact on the movement of people and their relationship to rural households of origin, two notable examples being high and rising unemployment and an increase in HIV prevalence and the incidence of AIDS. In times of ill health and labour market insecurity, rural areas may continue to provide a refuge for migrants (Wilkinson et al, 1998; Vaughan, 1997), as well as being a place for retirement (James, 2001).

The literature on migration in South Africa spans a range of disciplines and a diverse set of research literature. However, little has been written about macro trends in labour migration and remittance transfers in South Africa over the past ten years. Attempts to map changes over time using data from repeated cross-sections of a population are always susceptible to problems of comparability across surveys. In the case of labour migration, these problems are complicated by the declining coverage of labour migrants in household surveys in South Africa over time (Posel, 2002). Notwithstanding these limitations, we explore the data that are available in nationally representative household surveys for the period 1993 to 1999, and examine what these data can tell us about three questions. First, what is the extent of temporary labour migration within South Africa and what trends emerge in this migration? Second, who are the migrant workers, have there been any recorded changes and what would account for these changes? Third, what kinds of ties are labour migrants retaining with their households of origin and how have these ties changed over time?

The objective of the paper is not to provide comprehensive answers to these questions. Given the constraints imposed by the extent, quality and comparability of existing data, much of our analysis is simply descriptive and suggestive. However, the study seeks to highlight possible trends and relationships that could be explored further both in more qualitative research, and data permitting, in future empirical analysis.

We find that during the period under review, an increasing proportion of rural African households reported migrant workers as members of the household. Although there was little reported change in male labour migration from rural areas, female labour migration increased. As a result, there was a small but discernible shift in the gender composition of migrant workers in South Africa. Although there is evidence to suggest that some women may be migrating to join male partners, we find that women who are not married are more likely to migrate to work or to find work. Furthermore, the increase in female migration has occurred at the same time as a reported decline in marital rates among African women. We suggest that changes in women's relationships to men would be consistent both with there being an increased economic need for women to migrate, and with women having more freedom to move. We cannot investigate whether the temporary outmigration of people from rural areas precedes their permanent migration, nor, given the nature of the data, can we examine the question of return migration. However, we find that the proportion of households with migrant workers who retained economic ties increased over the period and that migrants closer to retirement age, remitted absolutely (and relatively) more than younger migrants. 


\section{The Data}

The data for the study come from the 1993 Project for Statistics on Living Standards and Development (PSLSD) and the 1995, 1997 and 1999 October Household Surveys. In 1993, the first comprehensive national household survey was introduced in South Africa. This survey, the PSLSD, was administered by the South African Labour and Development Unit (SALDRU) and sampled some 9000 households. In 1993, a national household survey was also introduced by the official statistical agency in the country, then known as the Central Statistical Services (CSS) and now as Statistics South Africa (Stats SA). The October Household Survey (OHS) was conducted annually from 1993 to 1999 . Because of differences in sampling methodology and coverage, the OHSs cannot be easily compared over time ${ }^{1}$. In this study, we analyse only the 1995, 1997 and 1999 OHSs, which seem to be compatible in terms of methodology and scope. There are still problems, however, with comparing information across the PSLSD and the OHSs, and between the OHSs themselves.

The two survey instruments adopt different methodologies in defining households, and by implication, in their treatment of labour migrants. The PSLSD survey begins with a broad definition of the household, allowing for the inclusion of household members who have lived in the household for at least 15 days of the previous year. Migrant household members therefore are directly included in the household roster and the same kind of demographic information is collected on all household members, whether they are resident in the household or absent for most of the year. The residency requirement for household membership is then tightened for the remainder of the survey where more specific information on household members (including that on employment status and income earned) is collected only for people who have been resident in the household for at least 15 out of the previous 30 days.

In contrast, the OHS adopts from the outset a stricter residency requirement in defining the household. Extensive individual demographic information is initially collected only on household members who are normally resident in the household for at least four days of the previous week, thereby excluding migrant household members from their households of origin. The 1997 and 1999 surveys, however, widen the definition of the household later in the questionnaire to capture information separately on migrant workers in the household of origin. In these two surveys a migrant worker is defined as 'someone who is absent from home for more than a month each year to work or to seek work' (1997 OHS questionnaire, p.34; 1999 OHS questionnaire, p. 29).

One of the problems with the approach used in the 1997 and 1999 OHSs is that unless questions asked of resident household members are duplicated for migrant workers, the same kind of information about both groups of household members will not be collected. In the OHSs specifically, we know far more about the characteristics of people who are resident in the household and about whom information is gathered in the household roster than we do about migrant workers.

The OHSs have also not been consistent in the kinds of questions that have been asked separately of migrants over the years. The 1997 OHS for example, asked respondents to identify the sex and education of the migrant worker. Respondents were asked also to identify whether or not the migrant was household head, but not the broader question of the migrant's relationship to the head (for those who were not heads of household) that is usually asked of all resident members of a household. In 1999, the survey included a smaller set of questions on migrant workers, with information captured on the sex and age of migrant workers but not on their education or headship.

In the $1995 \mathrm{OHS}$, no separate module on migrant workers is included and therefore migrant household members are not identified or recorded at households from which they have migrated. 
Rather, household respondents are asked to identify whether there are any household members who spend most of their time in the household, but who are also members of another household, in the sense that they are either 'working or looking for work away from what they call "home" ' (1995 OHS questionnaire, p.20). We suspect that identifying labour migration in this way, at the destination household rather than at the household of origin, has lead to an "undercount" of labour migration in 1995, an argument that we explore in more detail in Section 3.1 below.

These differences between the surveys make it difficult to provide a textured description and empirical analysis of labour migration patterns in the country at a national level. We do the best we can, given the data available to us, but we also highlight omissions in questions and likely biases, that limit the comparability of our findings over time (see Posel, 2002 for a more detailed description of problems with the data capture of migration in recent household surveys in South Africa).

\section{Patterns and Trends in Labour Migration, 1993-1999}

In this study, a migrant worker (or a labour migrant) is an individual who is identified as a member of the household but who is absent from that household for at least one month during the past year to work or to seek work ${ }^{2}$. As Table 1 indicates, most reported migrant workers in South Africa are African and the proportion of total migrant workers who are African is also increasing. The paper therefore focuses on questions about African labour migration in particular.

\section{Table 1: Migrant Workers by Race Group (15 years and older)}

\begin{tabular}{|l|c|c|c|c|}
\hline $\begin{array}{l}\text { Percentage of all Migrant } \\
\text { Workers who are: }\end{array}$ & $\mathbf{1 9 9 3}$ & $\mathbf{1 9 9 5}$ & $\mathbf{1 9 9 7}$ & $\mathbf{1 9 9 9}$ \\
\hline African & 92.0 & 90.5 & 95.6 & 96.1 \\
\hline Coloured & 2.9 & 6.1 & 3.8 & 3.2 \\
\hline Indian & 0.9 & 0.9 & 0.2 & 0.2 \\
\hline White & 4.3 & 2.5 & 0.4 & 0.5 \\
\hline Total Percent & 100.0 & 100.0 & 100.0 & 100.0 \\
\hline
\end{tabular}

Note: The data are unweighted

\subsection{The Extent of Labour Migration}

The migrant labour system has been a key feature in the development of South Africa. Africans were pushed into urban areas through the alienation of land and a series of state interventions to mobilise and control labour, and then pushed back to rural areas through a range of measures that made permanent urban settlement impossible for most migrants. With the lifting of restrictions on African urbanisation in the late 1980 s, a reasonable prediction is that circular or temporary migration in South Africa would be replaced by the permanent settlement of migrants at places of employment. However, as the data in Table 2 suggest, at least initially there does not seem to be strong empirical evidence supporting this prediction.

Between 1993 and 1999, the estimated number of households of all races that reported at least one labour migrant as a household member increased. This increase derived principally from the growth in the number of rural African households with migrant household members. Although the proportion of households of all races reporting labour migrants decreased slightly, there was a net increase in the proportion of African rural households containing at least one migrant worker.

2This definition of a migrant worker is specified in the 1997 and 1999 OHS questionnaires. It was possible to apply the same definition to the 1993 PSLSD data by combining information collected in the household roster on the period of absence of household members, and the reasons for this absence. In the $1995 \mathrm{OHS}$, a migrant worker is defined similarly but there is no mention of any time period.

Worker is defined similarly but there is no mention of any time period.
3 We have chosen not to weight any of the data in this table for the sake of comparability across the years. In the 1997 and 1999 OHSs, weights at the individual level are available for the total resident population. Because migrants are captured "outside" the total resident household roster, there are no weights available for migrant workers in these surveys. Where the data are reported at a household level, however, we do present the weighted figures because weights for households migrant workers in these surveys. Where the data are reported at a household level, however, we do present the we
that report migrant workers exist for all the years under review. We maintain this practice throughout the paper. 
Table 2: The Extent of Temporary Labour Migration across Households

\begin{tabular}{|l|c|c|c|c|}
\hline $\begin{array}{l}\text { Numbe r of Households with } \\
\text { at least one Migrant Worker: }\end{array}$ & 1993 & 1995 & 1997 & 1999 \\
\hline All Households & 1469300 & 803000 & 1610100 & 1779800 \\
\hline African Households & 1313300 & 753800 & 1557000 & 1722400 \\
\hline African Rural Households & 1170200 & $--^{5}$ & 1287500 & 1418400 \\
\hline $\begin{array}{l}\text { Percentage of Households with } \\
\text { at least one Migrant Worker: }\end{array}$ & & & & \\
\hline All Households & 17.8 & 8.8 & 17.4 & 16.5 \\
\hline African Households & 22.5 & 11.6 & 23.1 & 21.6 \\
\hline Rural African Households & 32.6 & -- & 37.6 & 35.8 \\
\hline
\end{tabular}

Note: Household weights are used in all years.

The data estimating the extent of migration in 1995 and 1997, however, need to be viewed with some caution. First, the coding of rural areas in the 1997 OHS is different to that in the other surveys. In the 1995 and 1999 OHSs, the data are coded so that 'rural' includes also semi-urban areas. In the 1997 OHS, however, Stats SA coded the sample so that 'urban' includes semi-urban areas and there is not enough information available in the data for us to be able to recode the sample for comparability. Because we would expect labour migration to be greater from rural areas than from semi-urban areas, it is likely that measures of rural migration in 1997 are overestimated.

Second, the data from the 1995 OHS appear to be inconsistent with the estimates of labour migration across households in the other years. We cannot think of any reason why the proportion of households with migrant workers should have decreased so dramatically between 1993 and 1995, only to have increased again in the subsequent years, outside of differences in data capture and sampling. In the 1995 OHS, migrant workers were identified not in the sending household but in the destination household. It may be, therefore, that the degree of clustering of migrant workers is greater in destination, than in sending, households. However, this would not be expected to affect the comparability of measures of migration at the individual level. It is therefore surprising, as Table 3 illustrates, that the proportion of African adults who are labour migrants calculated from the 1995 data is again far lower than that for the other years.

It seems that the recording of migrant workers at the households to which they have migrated leads to an estimation of labour migration that is less than that derived by counting labour migrants at the households from which migration has occurred. One explanation for this is that there may be differences in the identification of membership in the household of origin, by those who have remained behind and by those who have out-migrated. For example, parents may view their children who have left the household as continuing to have membership in that household, while the children, living in another household, do not ${ }^{5}$.

In turn, this could suggest that it would be incorrect simply to interpret adults, reported as migrant members in the household of origin, as circular or temporary migrant workers who oscillate between two "homes". At the least, the increase in the proportion of African rural households reporting migrant workers signals an increase in the out-migration of individuals from rural households to work or to find work. Nonetheless, as illustrated in Section 3.3, people who are identified at the household of origin as migrant household members mostly continue to retain strong (economic) ties with this household. 
Table 3: African Adults (15 years and older) who are Migrant Workers

\begin{tabular}{|l|c|c|c|c|}
\hline Percentage of: & $\mathbf{1 9 9 3}$ & $\mathbf{1 9 9 5}$ & $\mathbf{1 9 9 7}$ & $\mathbf{1 9 9 9}$ \\
\hline All Adults & $\mathbf{1 0 . 2}$ & 5.0 & 11.3 & 10.4 \\
\hline All Female Adults & 5.7 & 3.1 & 6.4 & 6.5 \\
\hline All Male Adults & 15.3 & 7.3 & 17.7 & 10.4 \\
\hline Rural Adults & 13.7 & -- & 14.6 & 14.4 \\
\hline Rural Female Adults & 7.4 & -- & 8.2 & 8.9 \\
\hline Rural Male Adults & 20.9 & -- & 22.2 & 20.4 \\
\hline Note:
\end{tabular}

Note: The data are unweighted.

Overall, there was little change in the percentage of all African adults (aged 15 years and older) reported as migrant workers between 1993 and 1999. However, the figures in Table 3 suggest that among rural adults specifically, there was a small net increase in labour migration over the period, driven by the rise in female migration. The majority of migrant workers in South Africa are men. However, the increase in female labour migration has resulted in a shift in the gender composition of labour migrants during the $1990 \mathrm{~s}^{6}$. Table 4 illustrates that in 1993 , an estimated 30 percent of African migrant workers in South Africa were women; by 1999, this had increased to approximately 34 percent of migrant workers.

Table 4: African Migrant Workers by Gender (15 years and older)
\begin{tabular}{|l|c|c|c|}
\hline Percentage of all Migrant Workers who are: & $\mathbf{1 9 9 3}$ & $\mathbf{1 9 9 7}$ & $\mathbf{1 9 9 9}$ \\
\hline Female & & & \\
\hline Male & 29.7 & 32.4 & 33.7 \\
\hline Total & 70.4 & 67.6 & 66.3 \\
\hline
\end{tabular}

Note: The data are unweighted

\section{Table 5: Proportion of African Migrant Workers by Age Cohort and Gender (Urban and Rural Combined)}

\begin{tabular}{|l|c|c|c|c|}
\hline & \multicolumn{2}{|c|}{1993} & \multicolumn{2}{c|}{1999} \\
\hline $\begin{array}{l}\text { Percentage in Age } \\
\text { Cohort: }\end{array}$ & $\mathrm{M}$ & $\mathrm{F}$ & $\mathrm{M}$ & $\mathrm{F}$ \\
\hline $15-19$ & 1.5 & 2.8 & 0.9 & 1.2 \\
\hline $20-24$ & 10.7 & 12.8 & 9.5 & 11.9 \\
\hline $25-34$ & 37.2 & 44.1 & 35.3 & 36.2 \\
\hline $35-44$ & 24.7 & 24.6 & 26.1 & 28.1 \\
\hline $45-54$ & 17.4 & 11.8 & 16.9 & 14.6 \\
\hline $55-64$ & 6.8 & 3.7 & 7.0 & 4.4 \\
\hline $65+$ & 1.9 & 0.2 & 4.3 & 3.6 \\
\hline Total & 100.0 & 100.0 & 100.0 & 100.0 \\
\hline Note: The data are unweighted & & & \\
\end{tabular}


It does not appear that the increase in female labour migration is being driven by a greater transition from school to work. Most African female migrants are between the ages of 25 and 44 years, but as Table 5 illustrates, between 1993 and 1999, a growing proportion were 35 years and older $^{7}$. In the next section, we explore other factors that may account for this rise in female labour migration.

The sample of migrant workers identified in the $1995 \mathrm{OHS}$ cannot be compared to the samples in the other surveys as a result of differences in the point of data capture on migrants. We therefore have excluded the 1995 data from the analysis of the gender composition and age distribution of migrants. However, because migrants were captured in the destination household in the 1995 survey, with these data we can identify the areas to which migration for work has occurred.

Urban areas usually are seen as centres of greater economic opportunity, and migration in South Africa conventionally is presented as a movement out of rural areas to urban destinations to find employment. A number of more recent regionally specific studies, however, have documented increased migration to semi-urban towns (Cross et al, 1998), to the rural perimeters of metropolitan areas (Cross et al, 1998), and between rural villages (Collinson 2001, and Collison and Wittenburg, 2001 and Vaughan, 1997). Furthermore, there is evidence that female labour migrants stay closer to home than male migrants (Wilkinson et al, 1998, on migration from the Hlabisa district of northern KwaZulu/Natal). The data from the $1995 \mathrm{OHS}$, reported in Table 6, provide support for these findings at a national level. In 1995, a significant proportion of the households to which people had migrated were located in rural (including semi-urban) areas. Female labour migrants also were more likely to be reported in rural, rather than in urban,

\section{Table 6: The Destination of African Labour Migrants (1995)}

\begin{tabular}{|l|c|c|c|}
\hline $\begin{array}{l}\text { Proportion of Labour Migrants } \\
\text { located in: }\end{array}$ & $\begin{array}{c}\text { All Labour } \\
\text { Migrants }\end{array}$ & $\begin{array}{c}\text { Male } \\
\text { Labour } \\
\text { Migrants }\end{array}$ & $\begin{array}{c}\text { Female } \\
\text { Labour } \\
\text { Migrants }\end{array}$ \\
\hline Urban Areas & 46.0 & 48.4 & 41.0 \\
\hline Rural Areas & 54.0 & 51.6 & 59.0 \\
\hline
\end{tabular}

Notes: Rural includes semi-urban areas. The data are weighted.

destination households.

Rising unemployment, the increasing informalisation of work, and resource constraints may be affecting where people move to in order to search for work. Migration into nearby towns rather than to more distant metropoles, for example, initially may be less costly for migrants. Furthermore, this "small-step" migration may make it easier for migrants to retain links to home areas, providing insurance in the event of unemployment or illness. In their work on migration in KwaZulu-Natal, Cross et al (1998) also suggest that insecurity about employment is increasing the desirability of a natural resource base. However, because low returns to agriculture necessitate multiple livelihood strategies, there is a movement to rural areas that are closer to employment centres. Additional reasons for why migration to the peripheries of urban areas or to smaller towns may be preferred to migration to cities include higher living costs, and perceptions of greater crime and violence, in the cities.

\subsection{Determinants of and Changes in Female Labour Migration}

The increase in female labour migration during the 1990s mirrors a more general increase in the proportion of all women who are working or wanting to work in South Africa. In an earlier paper (Casale and Posel, 2002), we suggested that it is unlikely that the broad change in female labour supply can be explained simply by a greater demand for female labour and an increase in 
employment opportunities for women. Female rates of unemployment in South Africa are rising and are considerably higher than male rates of unemployment. For example, using the OHS data, we estimated that in 1995, some 38 percent of all economically active women and 23 percent of all economically active men were broadly unemployed; in 1999, this had increased to 47 percent and 32 percent respectively. Furthermore, where women have found work, this seems to have been principally in self-employment in the informal sector, where women are creating work for themselves (Casale and Posel, 2002).

It is probable therefore that there have also been other changes pushing or encouraging more women to enter the labour force. Factors that we suggested might be particularly important are changes in household composition and women's marital status. Between 1993 and 1999, women were less likely to be living with men who had employment, a finding that partly reflects increasing rates of male unemployment. But marital rates during this period also declined, which may also account for why fewer women were living with men, irrespective of whether or not these men had employment ${ }^{8}$.

There are good reasons to suspect that similar changes within the household may be relevant in understanding an increase in female labour migration specifically. Feminist historians (cf. Bozzoli, 1983; Walker, 1990) who have sought to explain why most labour migrants in South Africa historically have been men, have pointed to the role of chiefs, fathers and husbands in restricting the mobility of women, thereby controlling women's sexuality and reinforcing women's traditional roles in rural production. More recently, in her study of cross-border migration from Lesotho, Zimbabwe and Mozambique to South Africa, Dodson found that the "women ... are more likely to be subject to the will of a (male) parent or partner in determining whether they will migrate" (Dodson, 2000:142). Todes reports similar findings in her study of migration in Newcastle, where she writes:

It was rare for women to experience the freedom of movement that men did... Women's mobility varied according to their position in the household. Married women could not move at will their husband's power in this regard was clearly apparent. Unmarried women were freer to move, but this depended on their position and conditions within the household. They were frequently constrained by their roles as care-givers responsibility for children, the sick and disabled, and for old parents (Todes, 2001:17,18).

If men restrict the mobility of women, then we would expect that women are more likely to migrate if they are not married and do not live with men not only because there may be a greater need for women to look for work but also because women have more freedom to move.

In order to explore these arguments further, we estimated a female "migration decision" equation using the 1993 PSLSD data. We were restricted to regression analysis that used only these data because of the incomplete coverage of the demographic characteristics of labour migrants in the 1997 and 1999 OHSs and concern with the suspected undercount of migrant workers in 1995. We therefore cannot compare estimated equations for female labour migration over the period under review and decompose the increase in female migration into changes arising from movements in the characteristics of the population and changes resulting from the underlying structure of the migration decision. Nonetheless, the regressions for 1993 help identify possible determinants of the subsequent rise in female labour migration.

${ }^{8}$ The causality in these relationships is, of course, difficult to specify. For example, it may be that because fewer women are living with men, women both have more control over how they allocate their labour and a greater need to look for work. But it could equally be argued that because more women are working or wanting to work, fewer women are forming permanent attachments with men or having children. 
In 1993, some 80 percent of all female African migrant workers migrated from households in rural areas in South Africa. In Table 7 we present the results of a probit regression that estimates the probability that an African woman, aged between 15 and 60 years and identified as a member of a rural household, is a migrant worker. We include a set of individual characteristics (marital

Table 7: Estimating African Female Labour Migration from Rural Areas, 1993

\begin{tabular}{|l|c|}
\hline & $\begin{array}{c}\text { Dependent Variabe } \\
\text { Married }\end{array}$ \\
Resident Employed Men & $-.97138^{*}$ \\
Male Migrant Workers & $-.06793)$ \\
& $\left(.0480^{* *}\right.$ \\
Land Size & $.27329^{*}$ \\
& $(.02942)$ \\
Children Aged 6 years or younger & $-.06978^{*}$ \\
Children Aged 7 to 14 years & $(.02761)$ \\
& $-.04268^{* *}$ \\
Women of Pension Age (60 and older) & $(.02069)$ \\
& $.03528^{* *}$ \\
Years of Education & $(.01809)$ \\
Age & $.14308^{*}$ \\
& $(.05326)$ \\
(Age) & $.02270^{*}$ \\
Constant & $(.00712)$ \\
Number of Observations & $.22038^{*}$ \\
\hline
\end{tabular}

1. Indicator variables for province were included in the estimation although the results are not reported here. 2. The regression is weighted. 3. Standard errors in parentheses. 4. * Significant at the 1 percent level; ** Significant at the 5 percent level.

status, age, years of education), household characteristics (the numbers of resident employed men, male migrant workers, women of pension age and children in the household, and the size of land to which the household has access) and province indicators.

The results of this regression suggest that women's relationships to men were significant in affecting the probability that women would migrate to places of employment. First, women who were married were significantly less likely than other African rural women to be migrant workers. Second, women were also less likely to migrate from households in which employed men were resident household members.

The fall in marital rates among African women between 1993 and 1999, reported in Table 8, therefore is likely to be important in understanding why more women have been migrating to find work over the period ${ }^{9}$. 


Table 8: Marital Rates Among African Women (15 years and older)
\begin{tabular}{|l|c|c|c|c|}
\hline & $\mathbf{1 9 9 3}$ & $\mathbf{1 9 9 5}$ & $\mathbf{1 9 9 7}$ & $\mathbf{1 9 9 9}$ \\
\hline Percentage who are: & & & & \\
\hline Married & 34.6 & 34.4 & 31.2 & 30.2 \\
\hline $\begin{array}{l}\text { Absent } \\
\text { Spouse/Divorced/ } \\
\text { Separated }\end{array}$ & $\begin{array}{c}\% \text { absent } \\
\text { spouse } \\
=13.4\end{array}$ & $\begin{array}{c}\% \text { divorced/ } \\
\text { separated } \\
=3.0\end{array}$ & $\begin{array}{c}\% \text { divorced/ } \\
\text { separated } \\
=3.1\end{array}$ & $\begin{array}{c}\% \text { divorced/ } \\
\text { separated } \\
=3.4\end{array}$ \\
\hline $\begin{array}{l}\text { Never } \\
\text { Married/Not } \\
\text { Married }\end{array}$ & 38.4 & 49.7 & 50.6 & 51.5 \\
\hline Widowed & 13.6 & 9.0 & 10.4 & 9.3 \\
\hline Living together Total & 100.0 & 100.0 & 100.0 & 100.0 \\
\hline \multicolumn{2}{|c|}{} & & & 5.7 \\
\hline
\end{tabular}

Note: Individual weights are used in all years.

The finding that women in 1993 were less likely to migrate from households in which employed men were resident household members is also echoed in the descriptive statistics across the years, reported in Table $9^{10}$.

Table 9: Percentage of Rural African Households with no Employed Men (aged 15-64 years)

\begin{tabular}{|l|c|c|c|}
\hline & 1993 & 1997 & 1999 \\
\hline With Female Labour Migrants & 79.3 & 86.2 & 83.1 \\
\hline Without Female Labour Migrants & 59.2 & 68.3 & 62.6 \\
\hline
\end{tabular}

Note: Weights are used in all years.

Table 10 describes the average number of employed men resident in African rural households with and without reported female labour migrants. In each year, households with female migrant workers contained significantly fewer employed men than households in which no women were reported as migrant workers. Furthermore, between 1993 and 1999, the average number of employed men resident in African rural households decreased.

Table 10: Average Number of Employed Resident Men (age64 5ears)in African Rural Households

\begin{tabular}{|l|c|c|c|}
\hline & 1993 & 1997 & 1999 \\
\hline With Female Migrants & 0.24 & 0.16 & 0.20 \\
\hline Without Female Migrants & 0.46 & 0.35 & 0.41 \\
\hline Note: Weights are used in all years.
\end{tabular}

Changes in household composition and marital rates, together with increasing job and income insecurity and rising levels of male unemployment, would have placed increased pressure on women to earn or generate an income ${ }^{11}$. At the same time, these changes may have meant that women face less (male) resistance within the household to their migration.

However, there is also evidence that female labour migration may be associated not only with women separating from men, but also with women joining men. In the regression reported in Table 7,

${ }^{10}$ As mentioned earlier, the 1997 data that capture the characteristics of rural households are likely to be "biased" by the exclusion of semi-urban areas from the rural classification. We would expect male employment in semi-urban areas to be higher than in rural areas, which may partly account for the peak in the 1997 estimates for the proportion of rural households without resident employed men in Table 9, and the dip in the average number of resident employed men in rural households in Table 10.

${ }^{11}$ An increase in the incidence of HIVIAIDs among (male) breadwinners would have placed additional pressure on women to find employment, but we have no data to explore this argument further. 
the probability that women are migrant workers is significantly increased in households that report male migrant workers ${ }^{12}$. This finding is consistent with a number of arguments. First, male migration may force women to migrate if, as suggested above, the absence of a resident employed male increases the economic necessity for women to work. Furthermore, if men, and particularly those in positions of authority, have migrated from the household, then women may also have more freedom to move. But another possible explanation for the positive relationship is that some women are migrating to join their partners or male family members, who provide support and networks in places of employment. We cannot ascertain from the data whether women are migrating alone or with men who migrated out of the same rural household, and whether women are migrating to the same households to which men have migrated. Slightly more than a third of rural African female migrants in 1993 were married; in households from which only one woman migrated, close to three quarters of these women reported spouses who were also migrant workers from the same rural households ${ }^{13}$. It is probable, therefore, that at least some percentage of these women were migrating with, or to join, their husbands.

Table 11 suggests that in all the years, a greater percentage of households with male migrant workers also contained female migrant workers, compared to those households without male migrants. However, this relationship may be weakening over time. Between 1993 and 1999, a larger percentage of households without male labour migrants reported female labour migrants as household members.

Table 11: African Rural Households with Male and Female Migrant
Workers
\begin{tabular}{|l|c|c|c|}
\hline $\begin{array}{l}\text { Percentage of Households } \\
\text { with Female Migrant Workers } \\
\text { in: }\end{array}$ & 1993 & 1997 & 1999 \\
\hline $\begin{array}{l}\text { Households with Male } \\
\text { Migrant Workers }\end{array}$ & 30.6 & 16.4 & 19.1 \\
\hline $\begin{array}{l}\text { Households without Male } \\
\text { Migrant Workers }\end{array}$ & 7.8 & 11.0 & 10.8 \\
\hline \begin{tabular}{l} 
Note: Weights are used in all years \\
\hline
\end{tabular}
\end{tabular}

Women's traditional roles in childcare and in farming would be expected to inhibit their migration to work in other areas. In the 1993 regression, women were significantly less likely to be migrant workers in households that had access to land. As the size of land increased, so the probability that women would migrate decreased, suggesting also that the need for women to find employment elsewhere was reduced. The number of young children (aged six years or less) resident in the household also reduced the probability of female labour migration, but women were more likely to migrate as the number of older children (aged 7 to 14 years) in the household increased. The direct costs of childcare rise as children get older, partly because of the costs of schooling, which may force women to look for employment and leave their children in the care of their grandmothers or other (female) relatives in the household. In our estimation, the probability of female labour migration increased as the number of female pensioners in the household increased. This finding could signal both the contribution of older women in childcare and the role of pension income in facilitating and supporting the migration of women.

${ }^{13}$ We were not able to calculate the proportion of all married African female labour migrants from rural areas whose husbands were also identified as migrant workers in the same household, because of the inability with the 1993 data to transpose information collected on the marital status of female migrants on information collected in the household roster when households reported more than one female labour migrant. 


\subsection{The Economic Ties of Labour Migrants}

Legislation preventing the urbanisation of national and cross-border migrants probably forced labour migrants to actively maintain connections with their rural community and family and helped to establish a pattern of oscillating migration in South Africa (see, for example, Beinart, 1980; Spiegel, 1980; Murray, 1981).

Studies historically have documented that remittances have been an important source of income for migrant households (Beinart 1980; Leliveld, 1997; Morapedi, 1999; James, 2001). But there are a number of reasons why it might be expected that the incentives for remitting income among migrants in South Africa are weaker now than they were before. The most obvious is the lifting of formal sanctions against African urbanisation and the greater possibility for the permanent settlement of migrant workers in urban areas. This may have been associated with more migrants being joined by their spouses and other immediate family members. It also may have increased the possibility for migrants to develop new and permanent ties in places of employment that would crowd out remittances to households of origin.

Conditions in rural areas have also changed. What seems to be a sustained decrease in agricultural and income-generating opportunities would have lowered the return to savings in these areas, particularly as alternative investments become more available to migrant workers. Furthermore, the extension of the social pension to all (age- and means-qualified) South Africans in 1992, and the high incidence of pension receipts in African rural households, may have reduced the need, or the perceived need, for the migrant to remit income ${ }^{14}$.

It is also not clear how changes in labour market conditions are affecting income transfers from migrants and the nature of rural-'urban' linkages. The ending of Apartheid has been associated not only with the elimination of formal restrictions on mobility and settlement, but also with a significant decline in the labour absorption capacity of the formal economy, the growth of more insecure forms of employment and a corresponding increase in unemployment. More insecure employment and a greater probability of becoming unemployed would be expected to increase the incentives for migrants to retain a rural alternative. But if more insecure employment is associated with employment at lower wages, then migrants may not have the resources to remit or to return home on visits. In this case, and as Sharp (2001:156) identifies in a study of migrants in Cape Town, it will be those migrants who have achieved "some form of modest security in the city" that can sustain rural relationships (see also Sporton et al's 1999 study of migration in the Kalahari).

Some more recent qualitative research and that based on smaller samples would seem to support the prediction that remittance transfers are falling. Cross et al (1998: 640), for example, argue that in many areas in KwaZulu-Natal, remittances as a share of household support are "shrinking" (although they do not quantify these shares). In his study of two migrant communities in the Northern (Limpopo) Province, Baber (1996:293) writes that investment in livestock has been reduced as "alternative savings instruments, such as pension and other savings policies with the major financial institutions have become more familiar to migrants". In a case study of migrants in Duncan Village in the Eastern Cape Province, Bank (2001:144) found that female migrants "preferred to invest their income in clubs and commodities rather than directly in the rural economy", in part because the former were seen to be better investments.

However, some work suggests also that traditional urban-rural ties based on agriculture and livestock have been replaced by housing, with migrants investing in rural houses for retirement (Todes, 1998; Larsson, 1998; James 2001). In her study of migrants in villages in the Northern Transvaal, James argues that part of the motivation for migrants wanting to retire in rural areas in 
the Northern (Limpopo) Province is that there would be no "unnecessary expenses" that would have to be incurred. But she observes also that ties to rural areas for retirement go beyond purely economic considerations: "Land represents a sense of security, identity and history, rather than being just an asset to be used for farming alone" (James, 2001:93).

Our investigation of how remittance transfers have changed between 1993 and 1999 is limited by the nature of the data available. In the $1995 \mathrm{OHS}$, no information on remittances was collected and in the 1999 OHS, respondents were asked to identify how often a migrant remitted, but not how much was remitted. We therefore can estimate the value of remittances only for the 1993 PSLSD and the 1997 OHS. Although the 1993 PSLSD collected the most comprehensive information on labour migrants of the surveys available, it is not possible to identify which labour migrant remitted what income with these data. The only way in which we can infer the identity of the remitter is by restricting the sample to all households that contained one labour migrant and that received one set of remittances. Because remittances from sole labour migrants may be higher than remittances sent when there is more than one migrant in the household, we have also reported data for the restricted sample in 1997. In the 1997 OHS, it is possible to identify how much each individual migrant remits, but very little additional information about migrant workers is collected (for example, we do not know the age or marital status of the migrant).

There is also the (inevitable) problem of selection bias in the data. Household members who have migrated, and who continue to be identified as members of the household of origin, are more likely to be remitting. Excluded from the sample of migrant workers therefore are those former household members who have migrated to places of employment, and who are no longer considered members of the sending household, perhaps because they have not retained (economic) ties with the household ${ }^{15}$.

We summarise what can be extracted from the national household survey data in Table 12. (For a more detailed study of the determinants of remittance transfers in a multivariate context in 1993, see Posel 2001). Between 1993 and 1999, a large and growing proportion of rural African households that reported at least one migrant worker as a household member also reported receiving remittances at least once in the previous year ${ }^{16}$. In 1993, for example, approximately 79 percent of all rural African households with migrant workers received remittance income; in 1999 this had increased to 85 percent. Furthermore, between 1993 and 1997, average yearly remittances in nominal terms increased by about 40 percent. 


\begin{tabular}{|c|c|c|c|}
\hline & 1993 & 1997 & 1999 \\
\hline $\begin{array}{l}\text { Percentage of Households with Reported } \\
\text { Labour Migrant/s Receiving Remittances }\end{array}$ & 78.5 & 84.2 & 85.4 \\
\hline $\begin{array}{l}\text { Average Yearly Value of Individual } \\
\text { Remittances sent by: } \\
\text { All Labour Migrants }\end{array}$ & $\begin{array}{l}2300.37 \\
(2117.89)\end{array}$ & $\begin{array}{l}3238.88 \\
(2800.25)\end{array}$ & --- \\
\hline Sole Labour Migrants & $\begin{array}{l}3173.10 \\
(2543.52)\end{array}$ & $\begin{array}{l}3736.09 \\
(3041.92)\end{array}$ & $\begin{array}{l}-- \\
--\end{array}$ \\
\hline $\begin{array}{l}\text { Remittances by Sole Labour Migrants Aged: } \\
\qquad 20-34 \text { years }\end{array}$ & $\begin{array}{l}2577.58 \\
(2230.79)\end{array}$ & -- & --- \\
\hline $35-49$ years & $\begin{array}{l}3383.79 \\
(2522.27)\end{array}$ & -- & --- \\
\hline $50-65$ years & $\begin{array}{l}3655.72 \\
(2918.77)\end{array}$ & -- & --- \\
\hline $\begin{array}{l}\text { Average Total Yearly Expenditure in } \\
\text { Remittance-receiving Households }\end{array}$ & $\begin{array}{l}11193.26 \\
(7948.47)\end{array}$ & $\begin{array}{c}7678.42 \\
(11248.68)\end{array}$ & --- \\
\hline
\end{tabular}

In 1993, older migrants remitted more on average than younger migrants. This finding may partly reflect a positive relationship between earnings and age. However, using the same data, Posel (2001) found that after controlling for the migrant's expected wage, migrant workers older than 50 years still remitted significantly more than other migrants ${ }^{17}$. One explanation that would be consistent with this finding is that migrants closer to retirement age are more likely to return to the rural household than younger migrants and that they remit more in anticipation of their retirement. Furthermore, norm-driven patterns of remittance (and investment) behaviour that may have been established when few urban opportunities existed, would be expected to be stronger among older migrants $^{18}$.

In 1993, remittance income on average represented approximately 32 percent of total household expenditure in remittance-receiving rural African households. In 1997, reported total household expenditure in the same grouping of households declined substantially at the same time as remittance income increased, with the result that the average remittance-share of total household expenditure rose dramatically to 84 percent. However, we think it highly unlikely that estimates of total household expenditure can be compared with any credibility across the surveys, given differences in how this information was captured. The 1993 PSLSD includes an extensive set of questions about household consumption and spending, and captures detailed information disaggregated by expenditure category. Furthermore, the estimate of total household expenditure includes an imputed value for subsistence production. In sharp contrast, the 1997 OHS captures

\section{3}

\footnotetext{
${ }^{17}$ Employment and earnings information for migrant household members was not collected in the 1993 PSLSD. Expected wages for migrant workers were calculated from an estimated wage equation for all Africans with employment.

${ }^{18}$ Following on from Section 3.3, it would be interesting to examine whether the increase in female migration has coincided with an increase in average remittances sent by female labour migrants. Unfortunately we cannot disaggregate remittances by gender in 1993 because of the problem with matching remittances to each individual remitter in these data.
} 
information on household expenditure in a single question without offering the respondent much detail on what should be included in the estimate, and there is no prompt to impute a value for own production consumed. It appears then that household expenditure was largely underestimated in 1997, with the result that the remittance-share of expenditure is likely to be inflated.

Our conclusions about changes in remittance transfers over time therefore are very modest. Between 1993 and 1999, a large and growing proportion of rural African households from which migration occurred reported receiving remittance income; and at the least, the value of these transfers continued to represent a significant share of the household's total expenditure.

\section{Conclusion}

It is clear from the national data that migrant labour is still an important feature of the South African labour market. Labour migration from African rural households has increased over the last decade, as has the proportion of these households receiving remittance income from migrant workers. The increase in labour migration has been driven by the rising proportion of women leaving rural areas to work or to find work. This trend has coincided with a decrease in marital rates among African women and a fall in the proportion of women living with men, and employed men in particular. It is likely that these changes, on the one hand, have created greater income insecurity in rural households pushing women into finding employment, and on the other hand, have allowed women greater freedom to leave the household to work or to search for work.

The extent of our analysis, however, has been restricted by the lack of comprehensive and reliable data on labour migrants in the national household surveys, an issue that we highlight throughout the paper. We have also tried to expose the problems of comparability that arise due to the lack of a consistent methodology for capturing migrant workers across the surveys. While many questions remain on the nature and causes of migration in South Africa, and on the implications of increasing labour market insecurity and rising HIV/AIDs infections, future research will largely depend on the quality of data that are produced at a national level and on the resolution of some of the concerns that we have identified in the national survey instruments. 


\section{References}

Baber, Rupert (1996). "Current Livelihoods in Semi-Arid Rural Areas of South Africa". In Land, Labour and Rural Livelihoods in Rural South Africa, edited by Michael Lipton, Frank Ellis and Merle Lipton, pp. 269-302. University of Natal: Indicator Press.

Bank, Leslie (1999). "Men with Cookers: Transformations in Migrant Culture, Domesticity and Identity in Duncan Village, East London". Journal of Southern African Studies 25(3).

Bank, Leslie (2001). "Living Together, Moving Apart: Home-made Agendas, Identity Politics and Urban-Rural Linkages in the Eastern Cape, South Africa". Journal of Contemporary African Studies 19(1).

Beinart, William (1980). "Labour Migrancy and Rural Production: Pondoland c.1900-1950". In Black Villagers in an Industrial Society, edited by Philip Mayer, pp. 81-108. Cape Town: Oxford University Press.

Bozzoli, Belinda (1985). "Migrant Women and South African Social Change: Biographical Approaches to Social Analysis". African Studies 44(1).

Casale, Daniela and Dorrit Posel (2002). "The Continued Feminisation of the Labour Force in South Africa: An Analysis of Recent Data and Trends". The South African Journal of Economics 70(1).

Case, Anne and Angus Deaton (1998). "Large Cash Transfers to the Elderly in South Africa". Economic Journal, 108.

Collison, Mark (2001). "Migration patterns and research in South Africa: Moving into the twenty-first century". Paper presented to the Mellon Meeting: "Strengthening Demography and Population Studies in South Africa", Johannesburg.

Collison, Mark and Martin Wittenberg (2001). "Labour Force Dynamics in a Rural Part of South Africa: The Agincourt Sub-district of the Northern Province, 1992-2000". Paper presented to the DPRU/FES Conference, "Labour Markets and Poverty in South Africa", Johannesburg.

Cross, Catherine, Mngadi Tobias and Themba Mbhele (1998). "Constructing migration: infrastructure, poverty and development in KwaZulu-Natal". Development Southern Africa 15(4).

Dodson, Belinda (2000). "Women on the move: Gender and cross-border migration to South Africa from Lesotho, Mozambique and Zimbabwe". In On Borders. Perspectives on International Migration in Southern Africa, edited by David A. McDonald, pp.119-150. New York: St Martin's Press.

James, Deborah (2001). "Land for the Landless: Conflicting Images of Rural and Urban in South Africa's Land Reform Programme". Journal of Contemporary African Studies 19(1).

Klasen, S and Woolard, I. (2000). 'Unemployment and Employment in South Africa, 1995 1997', Report to the Department of Finance, South Africa.

Larrson, Anne (1998). "Housing as a Strategy for Urban-Rural Linkages in Botswana". In Changing Gender Relations in Southern Africa: Issues of Urban Life, edited by A. Larsson, M. 
Mapetla, and A. Schlyter, pp.129-154. Lesotho: The Institute of Southern African Studies and the National University of Lesotho.

Morapedi,Wazha G. (1999). "Migrant Labour and the Peasantry in the Bechuanaland Protectorate, 1930-1965”. Journal of Southern African Studies 25(2).

Murray, Colin (1981). Families Divided. The Impact of Migrant Labour in Lesotho. Cambridge: Cambridge University Press.

Posel, Dorrit (2001). "How do households work? Migration, the household and remittance behaviour in South Africa". Social Dynamics, 27(1).

Posel, Dorrit (2002). "Moving out of the household and out of the household questionnaire: The coverage of labour migration in national surveys in South Africa (1993-2001)". Unpublished manuscript, University of Natal, Durban.

Sharp, John (2001). "Review Article. Copperbelt and Cape Town: Styles and Rural Connections in Comparative Perspective". Journal of Contemporary African Studies 19(1).

Spiegel, Andrew (1980). "Rural Differentiation and the Diffusion of Migrant Labour Remittances in Lesotho". In Black Villagers in an Industrial Society, edited by Philip Mayer, pp.109-168. Cape Town: Oxford University Press.

Todes, Alison (1998). "Gender, Place, Migration and Regional Policy in South Africa". In Changing Gender Relations in Southern Africa: Issues of Urban Life, edited by A. Larsson, M. Mapetla, and A. Schlyter, pp.309-330. Lesotho: The Institute of Southern African Studies and the National University of Lesotho.

Todes, Alison (2001). "South African Urbanisation Dynamics and the Normalisation Thesis". Urban Forum.

Vaughan, Anne (1997). "An Integrated Rural Development Strategy for KwaZulu Natal. Towards the Formulation of an Effective Policy". Transformation 33.

Walker, Cherryl (1990). "Gender and the Development of the Migrant Labor System c.18501930: An Overview". In Women and Gender in Southern Africa to 1945, edited by Cherryl Walker, pp.168-196. Cape Town: David Philip Publishers.

Wilkinson, D., Connolly, A., Harrison, A., Lurie, M. and S. Abdool Karim (1998). "Sexually Transmitted Syndromes in Rural South Africa: Results from Health Facility Surveillance". Sexually Transmitted Diseases 25. 